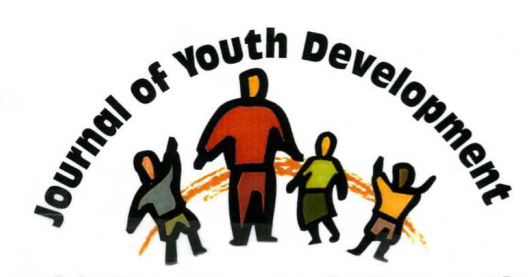

Bridging Research \& Practice

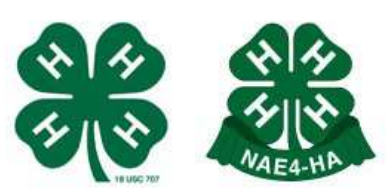

\title{
Demographic Differences in Patterns of Youth Out-of-School Time Activity Participation
}

\author{
Suzanne M. Bouffard \\ Harvard Family Research Project \\ Harvard Graduate School of Education \\ Harvard University \\ suzanne bouffard@harvard.edu \\ Christopher Wimer \\ Harvard Family Research Project \\ Harvard Graduate School of Education \\ Harvard University \\ wimer@fas.harvard.edu \\ Pia Caronongan \\ Harvard Family Research Project \\ Harvard Graduate School of Education \\ Harvard University \\ caronopi@gse.harvard.edu \\ Priscilla M.D. Little \\ Harvard Family Research Project \\ Harvard Graduate School of Education \\ Harvard University \\ priscilla little@harvard.edu \\ Eric Dearing \\ Department of Psychology \\ University of Wyoming \\ deariner@uwyo.edu \\ Sandra D. Simpkins \\ Department of Family and Human Development \\ Arizona State University \\ sandra.simpkins@asu.edu
}




\title{
JOURNAL OF YOUTH DEVELOPMENT \\ bridging research and practice

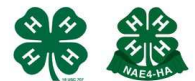

Volume 1, Number 1, Spring 2006

Article 0101FA004

\section{Demographic Differences in Patterns of Youth Out-of-School Time Activity Participation}

Suzanne M. Bouffard, Christopher Wimer, Pia Caronongan, and Priscilla M.D. Little Harvard University

\author{
Eric Dearing \\ University of Wyoming \\ Sandra D. Simpkins \\ Arizona State University
}

Abstract: Participation in structured out-of-school time (OST) activities is of growing interest to families, youth practitioners, and policymakers. OST activities benefit youth socially, emotionally, and academically, especially at-risk youth. Yet, little research has explored the characteristics of youth participants. This study examines whether demographic differences exist merely in getting youth "in the door" of activities, or whether differences persist when examining the number of activities and the amount of time youth spend in activities once they are there. Results from two nationally representative datasets showed that disadvantaged youth were less likely to participate in a variety of activities than their peers, and participated in fewer numbers of activities. Among youth who did participate, Blacks and Hispanics participated less frequently in some activities, although Blacks participated more frequently in community-based youth programs. Implications for recruitment and retention are discussed, including the need for activity leaders to enhance efforts to attract and sustain disadvantaged and ethnic minority youth.

\section{Background}

The widening achievement gap in the United States, especially for some low-income children of color, has turned the spotlight on nonschool supports for children and families. These non- 
school contexts can enhance and promote learning and development, thereby complementing school day efforts (Weiss, Coffman, Post, Bouffard, \& Little, 2005). Chief among these supports are out-of-school time (OST) programs and activities, with national polling data indicating that at least 6.5 million children are enrolled in after school programs nationwide (Afterschool Alliance, 2004).

There is a growing belief, based in research and practice, that schooling is "necessary but not sufficient" for supporting a range of positive outcomes including academic achievement (Weiss et al., 2005). Understanding and promoting participation in OST activities is of growing interest to families, youth workers, policymakers, and researchers who want to understand how to maximize young people's experiences during the nonschool hours. Public attention to how youth spend their out-of-school time has increased due to several factors, including federal funding for the $21^{\text {st }}$ Century Community Learning Centers $\left(21^{\text {st }}\right.$ CCLC) after school program initiative. Other driving factors include statistics showing that the after school hours are the peak time for crimes involving juveniles (Newman, Fox, Flynn, \& Christeson, 2000), increased maternal employment (U.S. Bureau of Labor Statistics, 2003), and parents' concerns about where their children spend the nonschool hours (Duffet, Johnson, Farkas, Kung, \& Ott, 2004).

OST activities, such as sports, school clubs, school-based and community-based after school programs, can benefit youth participants socially, emotionally, and academically (Eccles \& Barber, 1999; Mahoney, Larson, Eccles, \& Lord, 2005; Simpkins, Little, \& Weiss, 2004). Some studies suggest that these activities have the greatest benefits for youth who are at risk of academic or social problems (Mahoney, 2000; Roeser \& Peck, 2003). Indeed, many communitybased and school-based after school programs make it part of their mission to reach youth who are at risk for these problems (Hirsch, Roffman, Deutsch, Flynn, Loder, \& Pagano, 2000).

Yet, little research to date has explored the characteristics of youth who participate in OST activities. This research is crucial in order to address issues of access and equity, to document gaps in service and needs for opportunities among certain groups of youth, and to promote interventions to increase participation among those least likely to participate, who may also be, paradoxically, most likely to benefit.

Previous research has documented participation patterns in specific samples, such as ethnic minority youth (Borden, Perkins, Villarruel, \& Stone, 2005) and at-risk urban youth (Pedersen \& Seidman, 2005). Survey research has described how families view the availability of after school programs (Duffet et al., 2004). However, few studies have provided national estimates of youth participation in a variety of OST activities, including school-based activities (such as sports, arts, and student government) and community-based activities (such as after school programs, youth groups, and recreation programs). Furthermore, previous studies have primarily examined demographic characteristics in isolation-that is, without examining multiple characteristics together (e.g. income, ethnicity, and gender).

Research to date has also been limited in its definition of participation, with most studies defining participation according to a binary "yes or no" distinction (Simpkins, Little, \& Weiss, 2004). However, utilizing multiple indicators of participation - including: absolute

participation (a general measure of whether youth participate or not, which does not take into account the amount of time), intensity of participation (frequency of participation within a certain time period, for example number of hours per week), and breadth of participation (the range or number of activities in which youth participate) can vastly enhance our understanding of attracting and sustaining participation in OST activities (Weiss, Little, \& Bouffard, 2005). 
To address these research gaps, this study investigated the question,

Do differences among demographic groups exist merely in the process of getting youth "in the door" or do these differences persist when examining two additional indicators of participation - the number of activities (breadth) and the amount of time youth spend in activities once they are there (intensity)?

Two nationally representative datasets are used to describe socioeconomic, ethnic, and gender differences in participation in a wide variety of OST activities, from elementary school through high school.

Implications of this study can be used by a broad range of stakeholders who work with and for youth. They can inform initiatives to target financial and human resources to youth programs; improve efforts to recruit and retain youth in activities; and drive future research on access to and desirability of activities for diverse groups of youth.

\section{Method}

Two national datasets, the Panel Study of Income Dynamics (PSID) and the National Education Longitudinal Study (NELS) were used in the study. These datasets provided rich information on OST participation and the different contextual factors that may be associated with participation. Using the appropriate sampling weights, data from these two studies are nationally representative of the U.S. population.

\section{Panel Study of Income Dynamics (PSID)}

The Panel Study of Income Dynamics (PSID) is a nationally representative longitudinal survey that collects data on individuals from over 7,000 families. This study began in 1968 and is continuously expanding to include families of children from earlier waves who have now become heads of households themselves. The PSID's Child Development Supplement (PSIDCDS) began in 1997 to gain detailed information about children's experiences based on information from children, their caregivers, and other important figures in their lives. The respondents for the base year PSID supplement consisted of over 3,500 randomly selected 012 year-old children from the main PSID sample. A second wave of data was collected in 2002 for nearly 3,000 children whose families had remained active in the study. OST activity data for the current study are taken from the 2002 wave, when children were ages 5-19.

\section{National Education Longitudinal Study (NELS)}

The National Education Longitudinal Study (NELS) followed a nationally representative sample of eighth graders, from whom data were first collected in 1988. In the base year, 1,000 public and private schools were selected, with approximately 24 students randomly selected from each participating school. Four waves of data collection followed the base year in 1990, 1992, 1994, and 2002. Youth self-report data were supplemented with additional information collected from parents, teachers, and school administrators. This paper uses data from 1990 and 1992 (when most students were in $10^{\text {th }}$ and $12^{\text {th }}$ Grade, respectively), because these two waves included information on all three indicators of OST participation. 


\section{Instruments}

\section{Demographic Variables}

Parents' education. In both datasets, we created a four-category parental education variable, measuring how much education parents had completed. The four categories were less than high school, high school graduate or GED, some college, and college or postgraduate. In NELS, this variable is based on the parent with the higher education level; in PSID, it is based on the education level of the head of the household/primary caregiver.

Income. We created a measure of family income quintiles by dividing total family income by family size and dividing the sample into five groups, with the highest income families in the top quintile and the lowest income families in the bottom quintile. Because PSID includes separate family income measure for each year, the income quintile measure was created by averaging each family's income from 1994-2000, divided by family size from the same years. In NELS, income quintiles were based on data from the base year (1988), or from the second follow-up (1992) when base-year data were unavailable.

Ethnicity and gender. Dummy variables were created for each ethnicity and gender category, with Whites and males as the omitted reference categories. For comparability between the two datasets, we only report results for Whites, Blacks, and Hispanics.

Descriptive statistics on these four demographic characteristics are presented in Table 1 for each dataset.

Table 1

Demographic Distribution of NELS and PSID samples

\begin{tabular}{|l|c|c|}
\hline & NELS & PSID \\
\hline Female & $49 \%$ & $50 \%$ \\
\hline White & $67 \%$ & $46 \%$ \\
\hline Black & $12 \%$ & $41 \%$ \\
\hline Hispanic & $13 \%$ & $7 \%$ \\
\hline Income quintiles (range of per capita income* & \\
\hline 1 & $\$ 0-\$ 3,125$ & $\$ 542-\$ 5,466$ \\
\hline 2 & $\$ 3,214-\$ 5,833$ & $\$ 5,490-\$ 9,221$ \\
\hline 3 & $\$ 6,000-\$ 8,500$ & $\$ 9,223-\$ 13,139$ \\
\hline 4 & $\$ 8,750-\$ 12,500$ & $\$ 13,140-\$ 19,096$ \\
\hline 5 & $\$ 14,167-\$ 100,000$ & $\$ 19,100-\$ 182,762$ \\
\hline Parents' education & $11 \%$ & $21 \%$ \\
\hline Less than HS & $20 \%$ & $34 \%$ \\
\hline HS or GED & $38 \%$ & $25 \%$ \\
\hline Some college & $31 \%$ & $21 \%$ \\
\hline \multicolumn{2}{|l|}{ College or post-graduate } & $\begin{array}{l}\text { *Family income was divided by family size, and income quintiles represent per- } \\
\text { person income. }\end{array}$ \\
\hline
\end{tabular}




\section{OST Activity Participation}

Participation in OST activities was measured using a variety of items from both datasets. In NELS, we used data from student questionnaires collected at $10^{\text {th }}$ and $12^{\text {th }}$ Grade. Youth reported on their participation in youth groups/recreation programs, arts lessons, sports lessons, and school extracurricular activities. In PSID, we used activity participation indicators from the 2002 child and caregiver interviews. Youth ages 10-19 were asked about their participation in school-based extracurricular activities and organized sports or recreation programs occurring after school or during the summer. For youth of all ages, caregivers were asked questions about youth's participation in before and after school programs, summer camp, and scouting. In each dataset, the OST activity items were used to create three sets of participation indicators.

Absolute participation. To create measures of absolute participation for NELS, the original scale for each item, which indicated varying levels of participation, was collapsed into a dichotomous variable, where any amount of participation was coded as 1 . PSID youth and caregiver interviews included questions on which respondents indicated participation by answering yes/no.

Intensity. In NELS, intensity was captured in the form of number of hours of participation per week, ranging from 0-20+ hours/week for school extracurricular activities in $10^{\text {th }}$ Grade (0-25+ hours/week in $12^{\text {th }}$ Grade), and on a 4-point scale from rarely or never to every day or almost every day for the other items. PSID measured intensity of participation with a 6-point scale ranging from less than once a month to every day. Caregivers indicated intensity of participation in before/after school programs and summer camps in the form of hours per week. (It is worth noting that for these two indicators, caregivers were asked about their child's participation in such activities as a form of child care. Thus, these indicators may not capture before/after school or summer camp participation that is undertaken for non-child-care related motivations.)

Breadth. To create a measure of breadth in each dataset, the (dichotomous) absolute indicators were combined into a total score, ranging from 0-4 in NELS, and 0-5 in PSID.

\section{Data Analysis}

For each dataset, three sets of analyses were run, corresponding to the three indicators of participation. For absolute participation, multiple logistic regression models were run predicting whether youth participated at all in each activity (i.e., absolute participation).

For intensity and breadth, multiple linear regression models were run predicting the continuous outcomes of time spent in each type of activity (intensity) or number of activities (breadth). The intensity models included only those youth who reported spending at least some time in the activity, in order to test the association between intensity and demographics over and above absolute participation. For the same reason, the breadth models included only those youth who reported participating in at least one activity.

All models used dummy variables for ethnicity, with White as the reference group. All analyses used the appropriate sampling weights to calculate the Taylor Series Estimation procedure for complex survey designs, in order to address the problem of inflated standard errors. NELS 
analyses also used a stratification variable and a primary sampling unit variable (i.e., school) in calculating the Taylor Series Estimates.

\section{Results}

Tables 2 and 3 describe the level of participation in each activity, as measured by the three indicators, for the entire PSID and NELS samples, respectively.

In PSID, the majority of youth (68\%) participated in at least one of the five OST activities that we examined. Participation was highest in school extracurricular activities and sports, and lowest in before/after school programs and summer camp. Among before/after school program and summer camp participants, whose caregivers reported the intensity of youth's participation as a primary child care arrangement, the median intensity was relatively high (10 and 34 hours per week, respectively), while the median intensity for other activities ranged from once per week to several times per week. Among participants, the median number of activities was one activity.

In NELS, approximately three quarters of youth participated in at least one activity in both $10^{\text {th }}$ and $12^{\text {th }}$ Grade. Participation was highest in school extracurricular activities and youth groups/recreation programs. Among participants, the median intensity was approximately once or twice per week. The median number of activities among participants was two activities.

Table 2

Percentages, means, and median responses on PSID OST participation indicators

\begin{tabular}{|l|l|}
\hline $\begin{array}{l}\text { Activity and participation } \\
\text { indicator }\end{array}$ & $\begin{array}{l}\text { Percentage, mean, or median } \\
\text { response }\end{array}$ \\
\hline Absolute Participation (\%) & \\
\hline Before or after school program & $6 \%$ \\
\hline Summer camp & $9 \%$ \\
\hline School extracurricular activities & $46 \%$ \\
\hline $\begin{array}{l}\text { Organized summer or after school } \\
\text { sports or recreation programs }\end{array}$ & $41 \%$ \\
\hline Scouting & $13 \%$ \\
\hline $\begin{array}{l}\text { Intensity (median among } \\
\text { participants) }\end{array}$ & \\
\hline Before or after school program & $10 \mathrm{hrs} / \mathrm{wk}$ \\
\hline Summer camp & $34 \mathrm{hrs} / \mathrm{wk}$ \\
\hline School activities & Once a week \\
\hline $\begin{array}{l}\text { Organized summer or after school } \\
\text { sports or recreation programs }\end{array}$ & Several times a week \\
\hline Scouting & Once a week \\
\hline $\begin{array}{l}\text { Breadth (median number of } \\
\text { activities among participants) }\end{array}$ & 1 \\
\hline
\end{tabular}


Table 3

Percentages, means, and median responses on NELS OST participation indicators

\begin{tabular}{|l|c|c|}
\hline $\begin{array}{l}\text { Activity and participation } \\
\text { indicator }\end{array}$ & $\mathbf{1 0}^{\text {th }}$ Grade & $\mathbf{1 2}^{\text {th }}$ Grade \\
\hline Absolute Participation (\%) & & \\
\hline $\begin{array}{l}\text { Any OST Activity (among the } \\
\text { categories below) }\end{array}$ & $76 \%$ & $77 \%$ \\
\hline Youth Group/Recreation Program & $38 \%$ & $37 \%$ \\
\hline Arts Lessons & $26 \%$ & $15 \%$ \\
\hline Sports Lessons & $19 \%$ & $11 \%$ \\
\hline School Extracurricular Activities & $61 \%$ & $69 \%$ \\
\hline $\begin{array}{l}\text { Intensity (median among } \\
\text { participants) }\end{array}$ & & \\
\hline Youth Group/Recreation Program & Once or twice a week & Once or twice a week \\
\hline Arts Lessons & Once or twice a week & $\begin{array}{c}\text { Once or } \\
\text { twice a week }\end{array}$ \\
\hline Sports Lessons & Once or twice a week & Once or twice a week \\
\hline School Extracurricular Activities & $1-4$ hours per week & $5-9$ hours per week \\
\hline $\begin{array}{l}\text { Breadth (median number of } \\
\text { activities among participants) }\end{array}$ & 2 & 2 \\
\hline
\end{tabular}

Results of the regression analyses are presented below, first for PSID and then for NELS. Tables 4-6 report the unstandardized regression coefficients and standard errors, as well as the level of statistical significance, for each activity and indicator of participation. These statistics provide a measure of the association between each demographic characteristic and each activity variable, independent of the other demographic characteristics.

\section{Panel Study of Income Dynamics (PSID)}

Table 4 summarizes the results of the regression analyses predicting absolute participation, intensity and breadth. 


\section{Table 4}

Unstandardized Regression Coefficients (Standard Error) of Demographic Characteristics Associated with OST Participation in PSID

\begin{tabular}{|c|c|c|c|c|c|c|}
\hline $\begin{array}{l}\text { Activity } \\
\text { Measure }\end{array}$ & Female & Black & Hispanic & Income & $\begin{array}{c}\text { Parent } \\
\text { Education }\end{array}$ & $\begin{array}{c}\text { Sample } \\
\text { Size }\end{array}$ \\
\hline \multicolumn{7}{|l|}{$\begin{array}{l}\text { Absolute } \\
\text { Participation }\end{array}$} \\
\hline $\begin{array}{l}\text { Before or after } \\
\text { school program }\end{array}$ & $\begin{array}{l}.34 \\
(.22)\end{array}$ & $\begin{array}{c}1.38^{* * *} \\
(.29)\end{array}$ & $\begin{array}{c}1.37 * * \\
(.40)\end{array}$ & $\begin{array}{l}.37 * * * \\
(.10)\end{array}$ & $\begin{array}{l}-.05 \\
(.11)\end{array}$ & 2,476 \\
\hline Summer camp & $\begin{array}{l}-.09 \\
(.18)\end{array}$ & $\begin{array}{c}1.09 * * * \\
(.23)\end{array}$ & $\begin{array}{l}-.47 \\
(.52)\end{array}$ & $\begin{array}{c}.40 * * * \\
(.09)\end{array}$ & $\begin{array}{l}.22^{*} \\
(.11)\end{array}$ & 2,476 \\
\hline School activities & $\begin{array}{l}.81 * * * \\
(.13) \\
\end{array}$ & $\begin{array}{c}.14 \\
(.18) \\
\end{array}$ & $\begin{array}{l}.20 \\
(.27) \\
\end{array}$ & $\begin{array}{l}.15^{*} \\
(.06) \\
\end{array}$ & $\begin{array}{l}.22 * * \\
(.08) \\
\end{array}$ & 1,624 \\
\hline $\begin{array}{l}\text { Organized summer } \\
\text { or after school } \\
\text { sports or recreation } \\
\text { proqrams }\end{array}$ & $\begin{array}{l}-.17 \\
(.13)\end{array}$ & $\begin{array}{l}.07 \\
(.18)\end{array}$ & $\begin{array}{l}-.43 \\
(.28)\end{array}$ & $\begin{array}{c}.24 * * * \\
(.06)\end{array}$ & $\begin{array}{l}.06 \\
(.07)\end{array}$ & 1,626 \\
\hline Scouting & $\begin{array}{l}.30 \\
(.16)\end{array}$ & $\begin{array}{c}-.78^{* * *} \\
(.20)\end{array}$ & $\begin{array}{l}-.75^{*} \\
(.35)\end{array}$ & $\begin{array}{l}.09 \\
(.08)\end{array}$ & $\begin{array}{l}.13 \\
(.09)\end{array}$ & 2,465 \\
\hline \multicolumn{7}{|l|}{$\begin{array}{l}\text { Intensity } \\
\text { (above yes/no) }\end{array}$} \\
\hline $\begin{array}{l}\text { Before or after } \\
\text { school program }\end{array}$ & $\begin{array}{l}-1.27 \\
(1.97)\end{array}$ & $\begin{array}{l}-2.04 \\
(3.05)\end{array}$ & $\begin{array}{c}-.23 \\
(3.08)\end{array}$ & $\begin{array}{l}-2.06^{*} \\
(.94)\end{array}$ & $\begin{array}{l}2.70 * * \\
(1.02)\end{array}$ & 2,476 \\
\hline Summer camp & $\begin{array}{c}2.17 \\
(29.40)\end{array}$ & $\begin{array}{c}-27.77 \\
(19.28)\end{array}$ & $\begin{array}{l}-46.37 \\
(28.51)\end{array}$ & $\begin{array}{l}17.04 \\
(9.90)\end{array}$ & $\begin{array}{c}2.07 \\
(13.27)\end{array}$ & 2,476 \\
\hline School activities & $\begin{array}{l}.67 * * * \\
(.10)\end{array}$ & $\begin{array}{l}-.19 \\
(.25)\end{array}$ & $\begin{array}{l}.25 \\
(.21)\end{array}$ & $\begin{array}{l}.16^{* *} \\
(.05)\end{array}$ & $\begin{array}{l}.11 \\
(.06)\end{array}$ & 1,623 \\
\hline $\begin{array}{l}\text { Organized summer } \\
\text { or after school } \\
\text { sports or recreation } \\
\text { programs }\end{array}$ & $\begin{array}{l}-.19 \\
(.14)\end{array}$ & $\begin{array}{c}.20 \\
(.18)\end{array}$ & $\begin{array}{l}-.21 \\
(.25)\end{array}$ & $\begin{array}{c}.29 * * * \\
(.06)\end{array}$ & $\begin{array}{l}.03 \\
(.08)\end{array}$ & 1,625 \\
\hline Scouting & $\begin{array}{l}.11 \\
(.08)\end{array}$ & $\begin{array}{c}-.37 * * * \\
(.08)\end{array}$ & $\begin{array}{c}-.29 * * \\
(.11)\end{array}$ & $\begin{array}{c}.02 \\
(.04)\end{array}$ & $\begin{array}{c}.07 \\
(.05)\end{array}$ & 2,465 \\
\hline Breadth & $\begin{array}{c}.07 \\
(.05)\end{array}$ & $\begin{array}{l}.10 \\
(.08)\end{array}$ & $\begin{array}{c}.09 \\
(.11)\end{array}$ & $\begin{array}{l}.08^{* *} \\
(.02)\end{array}$ & $\begin{array}{c}.03 \\
(.03)\end{array}$ & 1,614 \\
\hline
\end{tabular}

\section{Absolute participation.}

Controlling for the other demographic factors, family income was the most consistent demographic factor linked to absolute participation. Youth from higher income families more likely to participate in many activities -- before/after school programs, summer camp, school extracurricular activities, and sports/recreation programs. Higher parental education was associated only with participation in summer camp and school extracurricular activities. Blacks and Hispanics were more likely than Whites to be involved in before/after school programs and 
less likely than Whites to be involved in scouting; Blacks were also more likely than Whites to be involved in summer camps. There were no significant differences between boys and girls on most measures of absolute participation, although girls were more likely than boys to be involved in school extracurricular activities.

\section{Intensity.}

Some demographic characteristics were associated with intensity, even after accounting for absolute participation. Youth from higher income families not only participated more overall in school extracurricular activities and sports/recreation programs, they did so at higher intensity levels. In contrast, while youth from higher income families were more likely to participate in before/after school programs, those who participated did so at lower intensity levels. In contrast to this finding for income, higher parental education was associated with greater intensity of participation in before/after school programs. Ethnicity and gender were generally less associated with intensity than with absolute participation. Black youth who participated in scouting, however, did so for fewer hours per week than Whites.

\section{Breadth.}

Demographic factors were generally unrelated to the number of activities in which youth participated, over and above absolute participation in at least one activity. The one exception was family income: Children of higher income families were more likely than children of lower income families to participate in a greater number of activities. 


\section{National Education Longitudinal Study (NELS)}

Tables 5 and 6 summarize the results of the regression analyses predicting absolute participation, intensity, and breadth at $10^{\text {th }}$ and $12^{\text {th }}$ Grade, respectively.

Table 5

Unstandardized Regression Coefficients (Standard Error) of Demographic Characteristics Associated with $10^{\text {th }}$ grade OST Participation in NELS

\begin{tabular}{|c|c|c|c|c|c|c|}
\hline $\begin{array}{l}\text { Activity } \\
\text { Measure }\end{array}$ & Female & Black & Hispanic & Income & $\begin{array}{c}\text { Parent } \\
\text { Education }\end{array}$ & $\begin{array}{c}\text { Sample } \\
\text { Size }\end{array}$ \\
\hline \multicolumn{7}{|l|}{\begin{tabular}{|l|} 
Absolute \\
Participation \\
\end{tabular}} \\
\hline $\begin{array}{l}\text { Youth Group/ } \\
\text { Recreation Program }\end{array}$ & $\begin{array}{c}.19 * * * \\
(.06)\end{array}$ & $\begin{array}{c}.06 \\
(.10)\end{array}$ & $\begin{array}{c}.24 * * \\
(.08)\end{array}$ & $\begin{array}{l}.01 \\
(.02)\end{array}$ & $\begin{array}{l}.31^{* * *} \\
(.04)\end{array}$ & 15,311 \\
\hline Arts Lessons & $\begin{array}{l}.67^{* * *} \\
(.06)\end{array}$ & $\begin{array}{l}.07 \\
(.12)\end{array}$ & $\begin{array}{l}.04 \\
(.09)\end{array}$ & $\begin{array}{l}.06^{* *} \\
(.02)\end{array}$ & $\begin{array}{l}.23 * * * \\
(.03)\end{array}$ & 15,305 \\
\hline Sports Lessons & $\begin{array}{c}-.36 * * * \\
(.06)\end{array}$ & $\begin{array}{l}.00 \\
(.11)\end{array}$ & $\begin{array}{l}.22^{*} \\
(.09)\end{array}$ & $\begin{array}{l}.10 * * * \\
(.02)\end{array}$ & $\begin{array}{l}.20 * * * \\
(.03)\end{array}$ & 15,295 \\
\hline $\begin{array}{l}\text { School } \\
\text { Extracurricular } \\
\text { Activities }\end{array}$ & $\begin{array}{l}.20 * * * \\
(.06)\end{array}$ & $\begin{array}{l}-.07 \\
(.11)\end{array}$ & $\begin{array}{l}-.08 \\
(.08)\end{array}$ & $\begin{array}{l}.14 * * * \\
(.02)\end{array}$ & $\begin{array}{l}.31^{* * *} \\
(.03)\end{array}$ & 15,562 \\
\hline \multicolumn{7}{|l|}{$\begin{array}{l}\text { Intensity } \\
\text { (above yes/no) }\end{array}$} \\
\hline $\begin{array}{l}\text { Youth Group/ } \\
\text { Recreation Program }\end{array}$ & $\begin{array}{l}.04 \\
(.02)\end{array}$ & $\begin{array}{l}.14 * * * \\
(.04)\end{array}$ & $\begin{array}{l}.02 \\
(.05)\end{array}$ & $\begin{array}{l}.01 \\
(.01)\end{array}$ & $\begin{array}{l}.01 \\
(.02)\end{array}$ & 5,762 \\
\hline Arts Lessons & $\begin{array}{l}-.02 \\
(.04)\end{array}$ & $\begin{array}{l}-.09 \\
(.09)\end{array}$ & $\begin{array}{l}-.15^{*} \\
(.07)\end{array}$ & $\begin{array}{l}-.01 \\
(.01)\end{array}$ & $\begin{array}{l}-.02 \\
(.02)\end{array}$ & 4,185 \\
\hline Sports Lessons & $\begin{array}{l}-.05 \\
(.05)\end{array}$ & $\begin{array}{l}-.21 * * \\
(.08)\end{array}$ & $\begin{array}{l}-.01 \\
(.07)\end{array}$ & $\begin{array}{l}-.01 \\
(.02)\end{array}$ & $\begin{array}{l}-.04 \\
(.03)\end{array}$ & 3,066 \\
\hline $\begin{array}{l}\text { School } \\
\text { Extracurricular } \\
\text { Activities }\end{array}$ & $\begin{array}{c}-.24 * * * \\
(.03)\end{array}$ & $\begin{array}{l}-.11 \\
(.07)\end{array}$ & $\begin{array}{l}-.10 \\
(.06)\end{array}$ & $\begin{array}{l}.04 * * \\
(.01)\end{array}$ & $\begin{array}{l}.11^{* * *} \\
(.02)\end{array}$ & 9,937 \\
\hline Breadth & $\begin{array}{c}.10 * * * \\
(.02)\end{array}$ & $\begin{array}{l}.01 \\
(.06)\end{array}$ & $\begin{array}{l}.03 \\
(.05)\end{array}$ & $\begin{array}{l}.03 * * \\
(.01)\end{array}$ & $\begin{array}{l}.10^{* * *} \\
(.02)\end{array}$ & 11,836 \\
\hline
\end{tabular}


Table 6

Unstandardized Regression Coefficients (Standard Error) of Demographic Characteristics Associated with $12^{\text {th }}$ grade OST Participation in NELS

\begin{tabular}{|c|c|c|c|c|c|c|}
\hline $\begin{array}{l}\text { Activity } \\
\text { Measure }\end{array}$ & Female & Black & Hispanic & Income & $\begin{array}{c}\text { Parent } \\
\text { Education }\end{array}$ & $\begin{array}{c}\text { Sample } \\
\text { Size }\end{array}$ \\
\hline \multicolumn{7}{|l|}{$\begin{array}{l}\text { Absolute } \\
\text { Participation }\end{array}$} \\
\hline $\begin{array}{l}\text { Youth Group/ } \\
\text { Recreation Program }\end{array}$ & $\begin{array}{c}-.29 * * * \\
(.04)\end{array}$ & $\begin{array}{l}.39 * * * \\
(.10)\end{array}$ & $\begin{array}{l}-.00 \\
(.09)\end{array}$ & $\begin{array}{l}.03 \\
(.03)\end{array}$ & $\begin{array}{l}.26 * * * \\
(.04)\end{array}$ & 12,807 \\
\hline Arts Lessons & $\begin{array}{c}.40 * * * \\
(.07)\end{array}$ & $\begin{array}{l}.41^{* *} \\
(.15)\end{array}$ & $\begin{array}{l}.27 * \\
(.13)\end{array}$ & $\begin{array}{l}.08^{* *} \\
(.03)\end{array}$ & $\begin{array}{l}.24 * * * \\
(.05)\end{array}$ & 12,805 \\
\hline Sports Lessons & $\begin{array}{c}-.61^{* * *} \\
(.09)\end{array}$ & $\begin{array}{l}.31^{*} \\
(.15)\end{array}$ & $\begin{array}{l}.17 \\
(.14)\end{array}$ & $\begin{array}{l}.11 * * * \\
(.04)\end{array}$ & $\begin{array}{l}.13^{*} \\
(.05)\end{array}$ & 12,818 \\
\hline $\begin{array}{l}\text { School } \\
\text { Extracurricular } \\
\text { Activities }\end{array}$ & $\begin{array}{l}.08 \\
(.06)\end{array}$ & $\begin{array}{l}-.07 \\
(.14)\end{array}$ & $\begin{array}{l}-.05 \\
(.10)\end{array}$ & $\begin{array}{c}.14 * * * \\
(.03)\end{array}$ & $\begin{array}{l}.27 * * * \\
(.04)\end{array}$ & 13,364 \\
\hline \multicolumn{7}{|l|}{$\begin{array}{l}\text { Intensity } \\
\text { (above yes/no) }\end{array}$} \\
\hline $\begin{array}{l}\text { Youth Group/ } \\
\text { Recreation Program }\end{array}$ & $\begin{array}{l}-.07 * \\
(.03)\end{array}$ & $\begin{array}{l}.00 \\
(.05)\end{array}$ & $\begin{array}{l}.01 \\
(.05)\end{array}$ & $\begin{array}{l}-.02 \\
(.01)\end{array}$ & $\begin{array}{l}.04 \\
(.02)\end{array}$ & 4,778 \\
\hline Arts Lessons & $\begin{array}{l}.08 \\
(.05)\end{array}$ & $\begin{array}{l}.06 \\
(.09)\end{array}$ & $\begin{array}{l}-.17 \\
(.09)\end{array}$ & $\begin{array}{l}-.03 \\
(.02)\end{array}$ & $\begin{array}{l}.01 \\
(.03)\end{array}$ & 1,958 \\
\hline Sports Lessons & $\begin{array}{l}.00 \\
(.06)\end{array}$ & $\begin{array}{l}.03 \\
(.09)\end{array}$ & $\begin{array}{l}-.04 \\
(.09)\end{array}$ & $\begin{array}{l}.01 \\
(.02)\end{array}$ & $\begin{array}{l}-.05 \\
(.04)\end{array}$ & 1,402 \\
\hline $\begin{array}{l}\text { School } \\
\text { Extracurricular } \\
\text { Activities }\end{array}$ & $\begin{array}{c}-.48^{* * *} \\
(.05)\end{array}$ & $\begin{array}{l}-.01 \\
(.09)\end{array}$ & $\begin{array}{l}.10 \\
(.09)\end{array}$ & $\begin{array}{l}.04 * \\
(.02)\end{array}$ & $\begin{array}{l}.12 * * * \\
(.04)\end{array}$ & 9,579 \\
\hline Breadth & $\begin{array}{c}-.07^{* *} \\
(.03)\end{array}$ & $\begin{array}{l}.15^{* *} \\
(.05)\end{array}$ & $\begin{array}{l}.09 \\
(.05)\end{array}$ & $\begin{array}{l}.02 \\
(.01)\end{array}$ & $\begin{array}{c}.07 * * * \\
(.02)\end{array}$ & 10,058 \\
\hline
\end{tabular}

\section{Absolute participation.}

At both time points, youth whose families had higher incomes and more education were more likely to participate in a range of activities. The only activity category not associated with family income was youth groups/recreation programs.

There were also differences in participation by ethnicity and gender. In $10^{\text {th }}$ Grade, there were no significant differences between Blacks and Whites, while Hispanic youth were less likely than Whites to participate in youth groups/recreation programs but more likely than Whites to participate in sports lessons. In $12^{\text {th }}$ Grade, Black youth were more likely than White youth to participate in all categories except school extracurricular activities, and Hispanic youth were 
slightly more likely than Whites to participate in arts lessons. Boys were more likely to participate in sports lessons at both time points; girls were more likely to participate in arts lessons at both time points and also in school-based extracurricular activities at $10^{\text {th }} \mathrm{Grade}$. Interestingly, girls were more likely to participate in youth groups/recreation programs at $10^{\text {th }}$ Grade, but boys were more likely to participate at $12^{\text {th }}$ Grade.

\section{Intensity.}

There were fewer demographic differences in the intensity of youth's participation (that is, above and beyond absolute participation). Youth from higher income and more educated families participated more frequently per week in school extracurricular activities, but this was not true of other activities.

We also found a number of ethnic differences in intensity of participation in the $10^{\text {th }}$ Grade. Black youth participated more frequently in youth groups/recreation programs than White youth, but participated less frequently in sports lessons. Hispanic youth participated less frequently in arts lessons than White youth. Gender differences in intensity only surfaced for extracurricular activities in $10^{\text {th }}$ Grade. This is interesting because, although girls participated more than boys overall in school extracurricular activities, boys participated for more hours per week. Similarly, in $12^{\text {th }}$ Grade, boys participated for more hours per week, although they were not more likely than girls to participate overall.

\section{Breadth.}

As with intensity, demographic characteristics were associated with the number of activities in which youth participated, after taking into account whether they participated at all. Youth with more highly educated parents were involved in more activities at both time points, as were youth from higher income families at $10^{\text {th }}$ Grade. At $12^{\text {th }}$ Grade, Blacks participated in a greater number of activities than Whites. Girls participated in more activities than boys at $10^{\text {th }} \mathrm{Grade}$, but this pattern was reversed at $12^{\text {th }}$ Grade.

\section{Participation Patterns Across Datasets}

We found that in both the PSID and NELS datasets, socioeconomic background factors (parental education and family income) were most consistently linked with participation, especially absolute participation and breadth. Across the majority of activities, youth whose families had higher incomes and more education were more likely to participate, and to participate in more diverse activities than children from less advantaged families. In some cases, more advantaged youth also participated with greater intensity, especially in schoolbased activities.

There were also differences based on ethnicity and gender. In many cases, Black and Hispanic youth were as likely or more likely than Whites to participate in many activities (one notable exception being $10^{\text {th }}$ Grade youth groups/recreation programs for Hispanics). However we found the Black and Hispanic youth participated with less intensity in some activities, including lessons. In general, girls participated in more activities (except sports), but participated in school extracurricular activities with less intensity at the high school level.

\section{Implications for Practitioners and Other Youth Stakeholders}

By using two high quality, nationally representative datasets, this study documents significant demographic differences in OST activity participation. These differences are prevalent across 
several types of activities, across age groups, and over a time period of more than a decade. In general, advantaged youth were more likely than less advantaged youth to participate in most types of activities, in a greater number of activities, and, in some cases, with greater intensity within activities. Some ethnic and gender differences were also found, particularly for intensity.

These findings provide further evidence that many youth who are in greatest need of nonschool opportunities, and who may be most able to benefit, are participating less than their more advantaged peers. Although this message may not be new, the results from analysis of these national datasets lends credibility to the growing evidence base that we need to better target resources to underserved populations, especially focusing on low-income youth whose parents have minimal postsecondary education.

Youth from lower income and less educated families were consistently less likely to participate in a range of activities and settings, including both school-based activities and communitybased groups. Some of these activities (e.g. lessons and summer camps) are likely to require fees, but other activities that may not require fees were also associated with income. Youth from lower income families may have more competing work responsibilities after school, or they may experience transportation barriers.

The fact that income and parental education were independently related to participation suggests that socioeconomic status may influence participation in other ways as well, for example due to parents' own prior experiences with school activities or the way that different families spend their leisure time (Lareau, 2003). Research by Furstenberg and colleagues (1999) revealed that indicators of neighborhood disadvantage are linked with lower participation in OST community activities. Their findings on neighborhood factors, combined with our study's findings on family socioeconomic status, suggest a more pervasive and systemic policy issue about access to and participation in OST activities for disadvantaged youth.

A second important message from this study relates to recruitment and retention strategies and provides further evidence that OST activity leaders need to ramp up their efforts to attract and sustain disadvantaged youth in general, and pay particular attention to specific ethnic groups. As described by Lauver and Little (2005), traditional methods of recruitment do not work well for some youth and their families, and OST activity leaders and youth practitioners may need to conduct more tailored and targeted recruitment efforts to reach those who are least likely to participate. Our results suggest that this recruitment and retention challenge exists across a wide range of activities, including recreation programs, school-based activities, and sports. No single type of OST activity is "off the hook" from needing to address these challenges.

Finally, this study demonstrates the importance of using multiple indicators of participation to better understand participation patterns. Using the indicators of intensity and breadth, the study documents that demographic differences exist not only in absolute participation, but in the number of activities and frequency with which youth participate. There may therefore be demographic barriers not only to getting youth "in the door" but to keeping them involved with a consistent level of intensity, particularly for ethnic minority youth. This is important because research shows that youth who participate more frequently and for a longer period of time are more likely to benefit (e.g., Marsh \& Kleitman, 2002; Posner \& Vandell, 1999). A related point is that the same youth who participate in one activity are also more likely to participate in additional activities. Participation, then, becomes self-reinforcing-the more you are invovled, 
the more you want to be involved. This underscores the need to "find the right hook" to attracting and sustaining youth participation in a variety of OST activities (Lauver \& Little, 2005).

The demographic differences documented in this study may be due to several factors. The datasets do not allow us to determine whether differences among demographic groups are attributable to access (i.e., availability and affordability of activities), logistics (e.g., transportation to and from activities), desirability of and youth interest in activities, or other factors. Teasing apart these factors-and combinations thereof-will be an important area for future research with nationally representative samples. It will also be an important task for youth practitioners. For example, activity leaders should ask themselves what kinds of barriers nonparticipating youth may experience, and use this information to be creative about recruitment strategies (Lauver \& Little, 2005).

Our results also document some differences in participation by ethnicity and gender; however these differences were not as pronounced as the income and education findings. In many activities, Black and Hispanic youth were as likely as or more likely to participate than Whites. The results also suggest that Blacks and Hispanics may have been more likely than Whites to utilize community-based OST programs, such as after school programs and recreation programs. However, Black and Hispanic youth participants participated with less intensity in some activities, which suggests that leaders of these activities should pay special attention to retention among ethnic minority youth. Research should further explore the finding that girls participated in more activities and higher number of activities, but for fewer hours in some cases.

Inequity in access to nonschool supports, such as OST activities, can limit opportunities to engage in positive development experiences for some youth, and thus perpetuate chronic achievement gaps, especially for low-income and ethnic minority youth (Gordon, Bridglall, \& Meroe, 2004). Moving forward, it is imperative that OST activity leaders and policymakers alike seriously examine the growing evidence base that disadvantaged youth are less likely to participate in OST activities than their more advantaged peers.

\section{References}

Afterschool Alliance. (2004). America after 3 PM: A household survey on afterschool in America, executive summary. Washington, DC: Author.

Borden, L.M., Perkins, D.F., Villarruel, F.A., \& Stone, M.R. (2005). To participate or not to participate: That is the question. New Directions for Youth Development, 105, 33-50.

Duffet, A., Johnson, J., Farkas, S., Kung, S., \& Ott, A. (2004). All work and no play? Listening to what kids and parents really want from out-of-school time. New York: Public Agenda.

Eccles, J., \& Barber, B.L. (1999). Student council, volunteering, basketball, or marching band: What kind of extracurricular participation matters? Journal of Adolescent Research, 14(1), 1043.

Furstenberg, F.F., Cook, T.D., Eccles, J., Elder, G.H., \& Sameroff, A. (1999). Managing to make it: Urban families and adolescent success. Chicago: University of Chicago Press. 
Gordon, E., Bridglall, B.L., \& Meroe, A.S. (2004). Supplementary education: The hidden curriculum of high academic achievement. Lanham, MD: Rowman \& Littlefield.

Hirsch, B.J., Roffman, J.G., Deusch, N.L., Flynn, C.A., Loder, T.L., \& Pagano, M.E. (2000). Inner-city youth development organizations: Strengthening programs for adolescent girls. The Journal of Early Adolescence, 20, 210-230.

Lareau, A. (2003). Unequal childhoods: Class, race, and family life. Berkeley: University of California Press.

Lauver, S.C., \& Little, P.M.D. (2005). Finding the right hook: strategies for attracting and sustaining participation in after school programs. The School Administrator, 5(62), 27-30.

Mahoney, J.L. (2000). School extracurricular activity participation as a moderator in the development of antisocial patterns. Child Development, 71, 502-516.

Mahoney, J.L., Larson, R.W., Eccles, J.S., \& Lord, H. (2005). Organized activities as development contexts for children and adolescents. In J.L. Mahoney, R.W. Larson, \& J.S. Eccles (Eds.), Organized activities as contexts of development (pp. 3-22). Mahwah, NJ: Lawrence Erlbaum Associations.

Marsh, H.W., \& Kleitman, S. (2002). Extracurricular school activities: The good, the bad, and the nonlinear. Harvard Educational Review, 72, 464-514.

Newman, S.A., Fox, J.A., Flynn, E.A., Christeson, W. (2000). America's After-school Choice: The Prime Time for Juvenile Crime, or Youth Enrichment and Achievement. Washington, DC: Fight Crime: Invest in Kids.

Pedersen, S., \& Seidman, E. (2005). Contexts and correlates of out-of-school activity participation among low-income urban adolescents. In J.L. Mahoney, R.W. Larson, \& J.S. Eccles (Eds.), Organized activities as contexts of development (pp. 85-110). Mahwah, NJ: Lawrence Erlbaum Associations.

Posner, J.K., \& Vandell, D.L. (1999). After-school activities and the development of low-income urban children: A longitudinal study. Developmental Psychology, 35(3), 868-879.

Roeser, R.W., \& Peck, S.C. (2003). Patterns and pathways of educational achievement across adolescence: A holistic-developmental perspective. In S.C. Peck \& R.W. Roeser (Eds.), Personcentered approaches to studying development in context (pp. 39-62). San Francisco: JosseyBass.

Simpkins, S.C., Little, P.M.D., \& Weiss, H.B. (2004). Understanding and measuring attendance in out-of-school time programs. Cambridge, MA: Harvard Family Research Project.

Weiss, H.B., Coffman, J., Post, M., Bouffard, S., \& Little, P. (2005). Beyond the classroom: Complementary learning to improve achievement outcomes. Evaluation Exchange, 11(1), 2-6, 17. 
Weiss, H.B., Little, P.M.D., \& Bouffard, S.M. (2005). More than just being there: Balancing the participation equation. New Directions for Youth Development, 105, 15-31.

U.S. Bureau of Labor Statistics. (2003). Employment characteristics of families summary (Table 4). Retrieved February 5, 2005 from: http://www.bls.gov/news.release/famee.t04.htm

\section{Acknowledgements}

The authors wish to thank Heather B. Weiss, Kathleen McCartney, and Holly Kreider for their guidance and support on this project. The research presented here was funded by a grant from the William T. Grant Foundation.

Correspondence regarding this article may be directed to the first author at Harvard Family Research Project, Harvard Graduate School of Education, 3 Garden St., Cambridge, MA 02138, or by email at suzanne_bouffard@harvard.edu, or by phone at (617) 495-9108.

(C) Copyright of Journal of Youth Development Bridging Research and Practice. Content may not be copied or emailed to multiple sites or posted to a listserv without copyright holder's express written permission. Contact Editor at: patricia.dawson@oregonstate.edu for details. However, users may print, download or email articles for individual use.

ISSN 2325-4009 (Print); ISSN 2325-4017 (Online) 